å rekruttere donorer for enhver pris, og hvor langt skal man gå når det gjelder overtalelse? Hvor går grensen mellom sofistikert undervisningsbasert overtalelse og manipulasjon?

Forfatterne viser blant annet hvordan en storstilt og godt planlagt intervensjon for å øke rekrutteringen blant den asiatiskættede delen av befolkningen ble totalt undergravd av medieoppslag om ulovlig høsting og salg av organer ved et sykehus. Det understreker hvilket grunnstoff organdonasjon er laget av: tillit.

Bjørn Hofmann

Høgskolen i Gjøvik og Universitetet i Oslo

\section{Tatovering og piercing - ikke uten risiko}

Christa de Cuyper, Maria-Luisa Pérez-Cotapos, red.

Dermatologic complications with body art

Tattoos, piercings and permanent make-up

110 s, tab, ill. Heidelberg: Springer, 2010.

Pris EUR 75

ISBN 978-3-642-03291-2

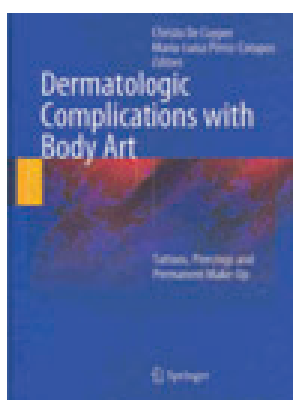

Folk tatoverer seg av mange grunner: for å markere tilhørighet til gruppe, støtte til fotballag, begeistring for rockeband, protest mot noe, alt eller intet, eller rett og slett fordi man synes det er pent. Tatoveringer er blitt mye vanligere de siste årene, også blant «alminnelig» ungdom. Det samme gjelder piercing - smykker gjennom hull laget i hud, øre, nese, tunge eller andre organer. Tatovering og piercing har gått fra å være et subkulturelt fenomen til å bli «mainstream». Likevel kan tatovering og piercing fortsatt være assosiert med risikoatferd, tilpasningsvansker eller psykiske plager.

Tatovering og piercing er i seg selv ikke risikofritt. Denne boken omhandler mulige hudkomplikasjoner etter tatovering, piercing og andre former for kroppsdekorering - eller kroppskunst, som det også kalles. Forfatterne er hudleger med særlig interesse for, og erfaring med, emnet. Boken er kort, bare 110 relativt store sider. Teksten er godt illustrert og med fyldige referanselister over relevante, vitenskapelige artikler. Først omtaler forfatterne historiske, kulturelle og epidemiologiske aspekter ved kroppsdekorering. Deretter beskriver de prosedyrer, materialvalg og hygieniske forholdsregler ved tatovering, inkludert permanent makeup, og ved piercing. Arrlaging (scarring), brenning (branding) og skjæring (cutting) omtales også. Størst plass er viet de vanligste formene for komplikasjoner, særlig ulike infeksjoner, kontaktallergi og skjemmende arr. Granulomatøse reaksjoner og kutan vaskulitt forekommer også. Til slutt beskriver de metoder for å fjerne tatoveringer, inkludert dermabrasio, eksisjon og laserbehandling. Bruk av Q-switch-lasere har gjort det mulig å oppnå ganske pene resultater, men komplett fjerning er det sjelden man får til. Fjerning er heller ikke bivirkningsfritt.

Denne boken vil interessere hudleger og plastikkirurger som trenger kunnskap om tatovering og piercing. Selv om boken er skrevet for medisinere i en nokså konvensjonell medisinsk publiseringsform, kan den være nyttig også for kroppsdekoreringsutøvere, som må kjenne til faren for komplikasjoner ved slike inngrep i normal hud.

\section{Petter Gjersvik}

Institutt for klinisk medisin

Oslo universitetssykehus, Rikshospitalet

\section{Nytenkning om smerter og funksjonssvikt}

Britt Fadnes, Kirsti Leira, Per Brodal Læringsnøkkelen

Om samspillet mellom bevegelser, balanse og læring. 195 s, ill. Oslo: Universitetsforlaget, 2010. Pris NOK 259

ISBN 978-82-15-01372-5

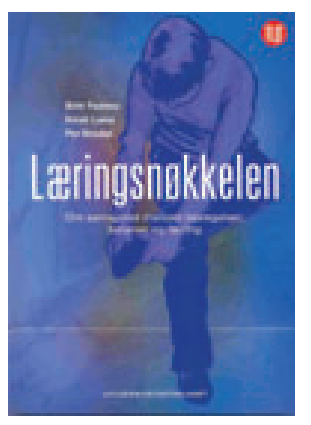

Målgruppen er fysioterapeuter, pedagoger og andre grupper av helsepersonell innen psykisk og somatisk helsearbeid. Forfatterne presenterer nytt og spennende fagstoff for alle som arbeider med

pasienter med smerter og funksjonssvikt.

Kunnskap innen nevrobiologi brukes som grunnlag for å utvikle balanse- og oppmerksomhetstrening. De gir eksempler på hvordan pasienter kan redusere sine smerter og bedre funksjonen gjennom å gjøre enkle, klart definerte oppgaver hjemme.

Leger vil ha nytte av å lese kapitlene Nevrobiologi og læringsorientert fysioterapi, Smerte som tolkning av kroppens tilstand, Ny forståelse av smerte - konsekvenser for praksis, Bevegelsesforstyrrelser hos noen pasienter med nevrologiske diagnoser og Intervju med to kroppsspesialister. Det er imidlertid de to resterende kapitlene, Bevegelse, balanse og læring og Balansekoden i praksis - en nøkkel til læring, som inneholder hovedbudskapet.

Noen vil oppfatte den konkrete og hver- dagslige formidlingen av fagstoffet $\mathrm{i}$ disse kapitlene som lite kunnskapsbasert, men forfatterne evner å illustrere balansekoden og bevegelse ved enkle, praktiske øvelser utmeislet gjennom mange års erfaring og langvarig samarbeid mellom to fysioterapeuter med psykomotorisk bakgrunn og en professor i nevroanatomi. Om denne tilnærmingen virker bedre enn tradisjonell psykomotorisk behandling eller kognitiv atferdsrettet behandling, kan ikke forfatterne gi svar på. Laringsnøkkelen er en videreføring av boken Balansekoden (2006) (1).

I Laringsnøkkelen har forfatterne forlatt tradisjonell psykomotorisk fysioterapi, respirasjonen er ikke vektlagt, og fagets nestorer finnes ikke i referanselisten. Det er naturlig at de tar utgangspunkt i nevrobiologi for forståelse av smerte og atferdsendring. God balanse krever stadig trening, skriver forfatterne, og bevegelsene er avhengige av at det sendes ut motoriske kommandoer før det er oppstått en forstyrrelse (feedforward-kontroll). Funksjonen til enkeltmuskler blir dermed bare interessant ved ulike bevegelser. Dette kunne forfatterne ha utdypet mer fordi medisinen og fysioterapien ofte begrenser seg til forsøk på å teste og palpere enkeltmuskler og se etter avvik ved hjelp av bildediagnostikk. Det gir ikke alltid svaret på funksjonsforstyrrelsen, og Laringsnøkkelen befinner seg på et høyere nivå. Forfatterne beskriver hvordan relativt nye forskningsmetoder kan måle økt eller hemmet aktivitet i områder av hjernen ved smerte og forventet smerte. Selv om vår forståelse av betydningen av dette fortsatt er begrenset, er samarbeidet mellom en professor i nevroanatomi og to psykomotoriske fysioterapeuter en spennende tilnærming til et fagområde som trenger nytenkning.

Teksten er lettlest, og nevrobiologien er fremstilt på en lettfattelig måte. Boken anbefales spesielt til leger som arbeider med pasienter der smertene og funksjonsforstyrrelsen er vanskelig å forstå.

\section{Jens Ivar Brox}

Ortopedisk avdeling

Oslo universitetssykehus, Rikshospitalet

\section{Litteratur}

1. Fadnes B, Leira K. Balansekoden. Oslo: Universitetsforlaget, 2006. 